\title{
ANALISIS PROBLEM GENDER PADA SINETRON DUNIA TERBALIK DALAM PERSPEKTIF NASARUDDIN UMAR
}

\author{
Nani Widiawati \\ Institut Agama Islam Cipasung Tasikmalaya \\ widiawatinani96@gmail.com \\ Nurkhopipah \\ Institut Agama Islam Cipasung Tasikmalaya \\ nurkhopipab@gmail.com
}

\begin{abstract}
Abstrak
Sinetron Dunia Terbalik yang mengungkap pertukaran peran gender dalam masyarakat merupakan fenomena yang menarik untuk dianalisis. Tulisan difokuskan untuk menemukan problem gender dalam sinetron Dunia Terbalik, prinsip-prinsip kesetaraan gender dalam perspektif Nasaruddin Umar, dan interpretasi gender dalam sinetron Dunia Terbalik berdasarkan pemikiran Nasaruddin Umar. Untuk itu, digunakan penelitian kualitatif dengan metode analisis isi terhadap sinetron tersebut sampai 150 episode versi youtube. Hasil penelitian menunjukkan bahwa problem gender dalam sinetron Dunia Terbalik adalah mengungkap pertukaran peran gender antara laki-laki dengan perempuan. Berdasarkan prinsip-prinsip kesetaraan gender menurut Nasaruddin Umar, dapat diinterpretasi bahwa persoalan pertukaran gender bukan hal esensial sebab, dalam pandangan Islam, laki-laki dan perempuan sama-sama sebagai hamba Allah, khalifah di bumi, menerima perjanjian primordial di mana Adam dan Hawa terlibat secara aktif dalam drama kosmis sehingga keduanya berpotensi meraih prestasi. Temuan ini sesungguhnya membuka ruang evaluasi bagi penggagasnya untuk membuka wawasan masyarakat dalam memahami persoalan gender sehingga makna pesan yang disampaikan tidak menjadi kontradiksi.
\end{abstract}

Kata Kunci: Gender, Sinetron, Dunia Terbalik

\section{Abstract}

The soap opera Dunia Terbalik, which reveals the exchange of gender roles in society, is an interesting phenomenon to analyze. The writing is focused on finding gender problems in the soap opera Dunia Terbalik, the principles of gender equality in the perspective of Nasaruddin Umar, and the interpretation of gender in the soap opera Dunia Terbalik based on the thoughts of Nasaruddin Umar. For this reason, qualitative research is used with the content analysis method to these soap operas up to 150 episodes of the YouTube version. The results showed that the gender problem in the soap opera Dunia Terbalik is to reveal the exchange of gender roles between men and women. Based on the principles of gender equality according to 
An-Nisa' : Jurnal Kajian Perempuan \& Keislaman

Vol. 14, No. 1, April 2021

p-ISSN : $2086-0749$

e-ISSN : 2654-4784

Nasaruddin Umar, it can be interpreted that the issue of gender exchange is not essential because, in the view of Islam, men and women are both servants of Allah, caliphs on earth, accepting the primordial agreement in which Adam and Eve were involved actively in the cosmic drama so that both of them have the potential for achievement. These findings actually open up an evaluation space for the initiators to open people's insights in understanding gender issues so that the meaning of the messages conveyed does not become a contradiction.

Keywords: Gender, Soap Opera, Dunia Terbalik 


\section{Pendahuluan}

Analisis gender merupakan cara untuk mengetahui keberadaan problem gender berdasarkan perbedaan jenis kelamin antara perempuan dan laki-laki. Dengan cara ini, kesenjangan gender dapat diidentifikasi sehingga faktor penyebab serta solusi masalahnya dapat ditemukan. Dalam analisis ini, secara umum yang menjadi fokus pembahasan adalah perempuan sekalipun studi gender sesungguhnya merekam kedua jenisnya, yaitu laki-laki dan perempuan, dan bahwa ketidaksetaraan gender sebenarnya menunjuk pada keduanya yang mana salah satunya menjadi korban. ${ }^{1}$ Fokus ini dikarenakan dalam relasi keduanya lahir fakta dan kasus ketidakadilan gender berdasarkan jenis kelamin yang dimilikinya, dan yang banyak dikorbankan adalah perempuan.

Manifestasi ketidakadilan gender, sebagaimana diungkap oleh pegiat gender, masih berkutat di isu-isu pelabelan, penomorduaan, peminggiran, beban ganda, dan kekerasan. Hal ini disebabkan karena realitas perbedaan jenis kelamin yang

1 R Dewi, 'Kedudukan Perempuan Dalam Islam Dan Problem Ketidakadilan Gender', Noura: Jurnal Kajian Gender Dan Anak, 2020.

2 Rusna Gani, 'ISLAM DAN KESETARAAN GENDER', AL-WARDAH, $12.2 \quad$ (2019) <https://doi.org/10.46339/al-wardah.v12i2.139>.

3 Elisabeth Tissier-Desbordes and Luca M. Visconti, 'Gender after Gender: Fragmentation, Intersectionality, and Stereotyping', Consumption Markets and Culture, 2019 <https://doi.org/10.1080/10253866.2018.1512238. kemudian berimplikasi pada pembagian peran gender yang dibentuk masyarakat. ${ }^{2}$ Manifestasi ketidakadilan tersebut masih dirasakan sampai hari ini sekalipun isu gender sudah bergulir sangat lama. ${ }^{3}$ Kasus yang relatif baru, antara lain diungkap beberapa peneliti dalam ranah pendidikan ${ }^{4}$, dan literasi. ${ }^{5}$ Keadaan ini bahkan terjadi di negara-negara yang didefinsisikan sebagai negara maju. ${ }^{6}$

Terdapat pendapat yang menyatakan bahwa manifestasi ketidakadilan gender tersebut, antara lain bersumber dari interpretasi agama dengan menunjuk beberapa ayat Alquran dan Hadis yang bersifat missogini, yaitu surat Al-A'raf: 189 yang menyatakan bahwa penciptaan perempuan bersifat sekunder, dan Hadis riwayat Bukhari dan Muslim tentang penciptaan perempuan secara material.

Disebut interpretasi, sebab Alquran sendiri sebenarnya menegaskan prinsip kesetaraan antara laki-laki dan perempuan. Dalam surat al-Nisa' ayat 1 dinyatakan bahwa laki-laki dan perempuan memiliki asal-usul yang sama. Dalam surat al-Ahzab ayat 35

\footnotetext{
4 Najamuddin Petta Solong and Rullyjanto Podungge, 'BIAS GENDER DALAM PENDIDIKAN ISLAM', Irfani, 2019 <https://doi.org/10.30603/ir.v15i1.1053>.

5 Elizabeth A. Bohls, 'Gender', in Handbook of British Travel Writing, 2020 <https://doi.org/10.1515/9783110498974-004>.

6 Thomas Breda and others, 'Gender Stereotypes Can Explain the Gender-Equality Paradox', Proceedings of the National Academy of Sciences of the United States of America, 2020 <https://doi.org/10.1073/pnas.2008704117>.
} 
diisyaratkan tentang kesamaan status keagamaan perempuan dengan laki-laki, sebagaimana status sosialnya.

Namun pada praktiknya, ketidakadilan gender masih termanifestasi dalam masyarakat. Hal ini tidak terlepas dari gagasan dasar mengenai gender sendiri. Bahwa gender secara konseptual menunjuk pada sistem peran dan relasi perempuan dengan lelaki yang batasannya ditentukan oleh budaya.

Dengan demikian, budayalah yang menentukan seperangkat peran, perilaku, kegiatan, dan atribut yang dianggap layak bagi laki-laki dan perempuan. Di dalam kebudayaan, batas-batas 'feminim' dan 'maskulin' didefinisikan, perilaku yang menjadi identitas laki-laki dan perempuan dibentuk, dan sifat-sifat individu, yang mencakup penampilan, pakaian, sikap, dan kepribadian dikukuhkan. $^{7}$

Labelitas identitas gender yang diidentifikasi pada perempuan atau laki-laki ditransmisikan secara turun temurun, antara lain melalui pendidikan. ${ }^{8}$ Transmisi tersebut dapat juga berlangsung melalui media massa. Di beberapa segmen acaranya, terdapat sisipan pesan budaya untuk melanggengkan harapan-

\footnotetext{
${ }^{7}$ Breda and others.

8 Ali Murfi, 'Bias Gender Dalam Buku Teks Pendidikan Agama Islam Dan Kristen', Jurnal Pendidikan Islam, $\quad 3.2 \quad$ (2014) <https://doi.org/10.14421/jpi.2014.32.267-288>.
}

harapannya. Kantor dan dapur masih menjadi wilayah yang konotasi gendernya kuat. Di iklan-iklan yang ditayangkan, antara lain konotasi tersebut ditegaskan. Untuk mengiklankan bumbu masak, sabun cuci, pemutih pakaian, pengharum ruangan, sampai iklan obat nyamuk yang penggunaannya berada di wilayah domestik, selalu diperankan oleh perempuan. Laki-laki hanya memerankan sebagai subjek yang menikmati hidangan makanan, memakai baju yang rapi, putih, dan harum, atau menikmati rumah yang nyaman sebab pekerjaan utamanya berada di wilayah publik, antara lain kantor. Contoh lain pada segmen film. Transmisi bias gender terlihat dalam tema-tema yang disampaikannya. ${ }^{9}$ Di segmen acara televisi, iklan dan film tentu saja bukan satu-satunya media. Di samping iklan, terdapat dialog, ceramah, atau sinetron.

Dari sifat penyebaran informasi melalui media massa, transmisi tersebut tampaknya cukup efektif. Seiring dengan perkembangan dinamika kehidupan masyarakat, peran dan fungsi media massa sebagai alat komunikasi semakin dominan digunakan dalam penyampaian pesan dan pembentukan opini

\footnotetext{
${ }^{9}$ Alicia Izharuddin, Gender and Islam in Indonesian Cinema, Gender and Islam in Indonesian Cinema, 2017 <https://doi.org/10.1007/978-981-10-2173-2>.
} 
masyarakat. Industri pertelevisian di Indonesia merupakan salah satu komoditas terbesar dan tidak ada habisnya. Berbagai macam televisi nasional bermunculan seperti RCTI, SCTV, Indosiar, NET TV, MNC TV dan sebagainya, saling berlomba untuk merebut minat pemirsa melalui tayangannya.

Peran dan fungsi televisi sebagaimana tersebut di atas, tampaknya seiring sejalan dengan budaya menonton pada masyarakat Indonesia sebagai salah satu kegiatan yang sangat digemari. Televisi menjadi media yang peminatnya paling banyak. Hampir setiap rumah yang terdapat di pedesaan maupun perkotaan mempunyai televisi. Dengan begitu, pelaku media massa terdorong untuk membuat beraneka ragam program acara. Genre program televisi begitu beragam.

Dari sekian banyak tayangan televisi, sinetron adalah tayangan yang cukup digemari mayoritas masyarakat Indonesia. Terkait dengan isu gender yang diungkap dalam tulisan ini, sinetron Dunia Terbalik RCTI, merupakan satu segmen yang menjadi fokus telaah. Hal demikian karena di sinetron tersebut mengangkat kisah kehidupan suatu masyarakat yang mana dalam aktivitas seharihari dalam berumah tangga tidak seperti kehidupan masyarakat pada umumnya. Dalam sinetron tersebut, suami melakukan aktivitas

10 Hesti Ratnasari and Departemen Ilmu Komunikasi, 'Penerimaan Khalayak Terhadap Pertukaran Peran Gender Antara Laki-Laki Dan layaknya seorang istri, seperti menjaga rumah, bersih-bersih rumah, mencuci pakaian, dan sebagainya, sampai urusan mengasuh anakanak. Sebaliknya, seorang istri melakukan aktivitas sebagai pencari nafkah yang dalam asumsi umum merupakan tugas laki-laki.

Cerita yang sederhana dan dekat dengan masyarakat menjadikan sinetron Dunia Terbalik menjadi idola masyarakat saat ini. Selain itu, sinetron Dunia Terbalik juga memberikan nilai yang dianggap positif dalam setiap tayangannya yang disuguhkan kepada penonton. Sehingga, sinetron Dunia Terbalik berhasil memeroleh Piagam Anugerah Syiar Ramadhan 2017 yang diberikan oleh Komisi Penyiaran Indonesia yang bekerja sama dengan MUI.

Keunikan dari isi sinetron tersebut, melahirkan ketertarikan tersendiri sehingga ada beberapa peneliti yang menyoroti hal ini. Pada sinetron tersebut, Hesti Ratnasari menemukan bahwa semua informan melakukan negosiasi posisi mengenai kesetujuan atau ketidaksetujuan mereka terhadap peran yang ditukarkan yang dikonstruksikan dalam sinetron tersebut. ${ }^{10}$

Irwanto, Nina Kusumawati, dan Laurensia Retno Hariatiningsih, pada elemen makro, penelitiannya menemukan keberadaan narasi feminisme dalam aspek persoalan

Perempuan Dalam Sinetron Dunia Terbalik Di RCTI', Interaksi Online, 2018. 
tenaga kerja, yang dalam konteks sinetron tersebut adalah tenaga kerja perempuan, yang dijadikan solusi untuk mencukupi kebutuhan keluarga. ${ }^{11}$

Agus Salim dan Mulharnetti Syas menemukan banyaknya pemirsa televisi yang terhibur melihat pertukaran peran dalam sinetron tersebut digunakan untuk membawa iklan yang menjadi bagian dari cerita dalam sinetron sehingga terbukti bahwa sinetron tersebut menjadi alat ekonomi politik yang menjadi komodifikasi konten-konten untuk Sinetron Dunia Terbalik di RCTI. ${ }^{12}$

Laurensia Retno Hariatiningsih menyatakan bahwa drama komedi ini sebenarnya mendasarkan diri pada narasi berbasis agama. Namun, di sisi lain sinetron ini mencoba tampil tidak menggurui dengan menceritakan sisi realitasnya sebagai bahan komedi. $^{13}$

Anisa Tri Amanda menyoroti sinetron ini pada aspek figur seorang ustadz. Menurutnya, deskripsi sosok Ustadz Kemed

${ }^{11}$ Irwanto, Nina Kusumawati, Laurensia Retno Hariatiningsih, "Narasi Feminisme dalam Sinetron Dunia Terbalik", Jurnal Ilmu Komunikasi, 2018, https://doi.org/10.31294/kom.v5i2.3871

12 Agus Salim dan Mulharnetti Syas, "Komodifikasi Pertukaran Peran Gender Pada Sinetron Dunia Terbalik Di RCTI” Jurnal Ilmu dan BudayaI, 2019, http://journal.unas.ac.id/ilmubudaya/article/view/709

13 Laurensia Retno Hariatiningsih, 'Persepsi Mahasiswa BSI Kaliabang Pada Tayangan Drama Komedi Dunia Terbalik Episode 151 Di RCTI ( Studi di sinetron tidak dibangun sebagai guru seperti dalam ajaran Islam yang sebenarnya. Dalam sinetron ini banyak penggambaran yang mendesakralisasi figur ustadz. ${ }^{14}$

Nuria Astagini dan Fitriyah Nurhidayah melihat kasus yang diangkat sinetron ini sebagai fenomena hiperrealitas. Penelitiannya menemukan bahwa hiperrealitas yang diperlihatkan pada sinetron ini merupakan starting point bagi diterimanya gagasan kesetaraan gender, serta dapat menghapuskan stigma negatif pada kalangan TKI beserta keluarganya. ${ }^{15}$

Muhammad Yusuf AR dan Atia Vitalia Aswadany melakukan penelitian berdasarkan persepsi para ibu rumah tangga. Penelitian ini menyimpulkan bahwa beberapa responden tidak setuju dengan pertukaran peran gender dalam sinetron Dunia Terbalik dengan alasan penyimpangan dengan norma budaya dan agama. Sementara responden yang setuju peran gender dalam sinetron tersebut beralasan bahwa seorang istri yang bekerja

Tentang Persepsi Mahasiswa BSI Kaliabang )', Cakrawala, 2018.

14 Anisa Tri Amanda, 'Desakralisasi Figur Ustadz Dalam Sinetron (Analisis Isi Terhadap Figur Ustadz Kemed Dalam Sinetron Dunia Terbalik Di RCTI)', KOMUNIKA, 2020 <https://doi.org/10.22236/komunika.v7i1.5566>.

15 Nuria Astagini and Fitriyah Nurhidayah, 'Hiperrealitas Sosok Suami Tenaga Kerja Wanita (TKW) Dalam Sinetron Dunia Terbalik Di RCTI', WIDYAKALA JOURNAL, 2017 <https://doi.org/10.36262/widyakala.v4i2.58>. 
untuk membantu suami mereka tidak tabu dan bisa diterima. ${ }^{16}$

Nola Filantrofi Rizki dan Lulus Irawati memokuskan telaahnya pada aspek pendidikan karakter. Hasil analisisnya menyatakan bahwa karakter-karakter yang positif dalam sinetron tersebut dapat disumbangkan kepada guru sebagai materi pembelajaran sastra Indonesia untuk tingkat Sekolah Menengah Pertama dan Sekolah Menengah Atas. ${ }^{17}$

Umaimah Wahid dan Ferrari Lancia menyoroti isu-isu paling dominan yang muncul di sepanjang sinetron, yaitu isu peran pria dan wanita di lingkup domestik dan publik, tentang partisipasi mereka dalam lingkup publik tetapi tidak mengesampingkan sifat domestik mereka yang dianalisis berdasarkan trilogi konteks situasi M. A. K Halliday. ${ }^{18}$

Tri Yuni Ariya memfokuskan diri untuk mencermati masalah resepsi terhadap pertukaran peran gender dengan responden pasangan-pasangan suami istri. Hasil

16 Muhammad Yusuf AR and Atia Vitalia Aswadany, 'PERSEPSI IBU RUMAH TANGGA TERHADAP PERAN GENDER PADA TAYANGAN SINETRON "DUNIA TERBALIK" RCTI', Jurnal Jurnalisa, 2019 <https://doi.org/10.24252/jurnalisa.v5i1.10172>.

17 Filantropi Nola Rizki and Lulus Irawati, 'Aspek Pendidikan Karakter Dalam Sinetron "Dunia Terbalik" Dan Sumbangannya Sebagai Materi Pembelajaran Sastra Indonesia Di Sekolah', Linguista: Jurnal Ilmiah Bahasa, Sastra, Dan Pembelajarannya, 2018 < https://doi.org/10.25273/linguista.v2i1.2687>. penelitiannya menunjukkan bahwa status sosial ekonomi informan memberikan makna yang berbeda dalam pembangunan pesan yang dibuat oleh anggota keluarga. ${ }^{19}$

Berdasarkan penelusuran penulis, belum ada kajian yang melihat problem gender dalam sinetron tersebut berdasarkan perspektif Islam. Penelitian yang menggunakan perspektif ini telah dilakukan oleh Ana Khoirun Nisak dalam skripsinya. Namun demikian, ia tidak mengaitkan peran perempuan dengan isu gender.

Atas dasar itu, penulis mencoba melakukan analisis terhadap sinetron tersebut sebagai bagian dari problem gender dengan menjadikan Islam sebagai sudut peninjauan dan lebih spesifik lagi berdasarkan perspektif Nasaruddin Umar, karena sinetron tersebut dalam banyak hal menggunakan simbol Islam. Dengan demikian, diharapkan dapat merepresentasikan kesetaraan gender dalam Islam pada tayangan sinetron.

Dengan menggunakan pendekatan kualitatif dan metode analisis isi (content

18 Umaimah Wahid and Ferrari Lancia, 'Exchange of Public and Domestic Roles of Men and Women in Indonesian Television Soap Opera "Dunia Terbalik" (Analysis of Social Discourse M. K. Halliday)', Advanced Science Letters, 2018 <https://doi.org/10.1166/asl.2018.12427>.

${ }^{19}$ Tri Yuni Ariya, 'Resepsi Pasangan Suami Istri Terhadap Pergeseran Peran Gender Dalam Sinetron Dunia Terbalik Rcti (Analisis Resepsi Model Stuart Hall)', Journal of Chemical Information and Modeling, 2018. 
An-Nisa' : Jurnal Kajian Perempuan \& Keislaman

Vol. 14, No. 1, April 2021

p-ISSN : $2086-0749$

e-ISSN : 2654-4784

analysis), pada awalnya penulis menganalisis episode 1 sampai 20, kemudian menambahkannya sampai episode 150 versi youtube. Upaya ini dilakukan untuk mengungkap problem gender dalam sinetron Dunia Terbalik, prinsip-prinsip kesetaraan gender dalam perspektif Nasaruddin Umar, dan interpretasi gender dalam sinetron Dunia Terbalik berdasarkan pemikiran Nasaruddin Umar.

\section{Pembahasan}

Sinetron Dunia Terbalik bergenre drama-komedi-islami yang tayang sejak 5 Januari 2017 merupakan produksi MNC Pictures dan disutradarai oleh Jonggi Sihombing. Sinetron Dunia Terbalik dibintangi oleh Agus Kuncoro (Akum), Sutan Simatupang (Aceng), Bambang Chandra Bayu (Idoy), Indra Birowo (Dadang), Mieke Amalia (Yoyoh), Felicya Angelista (Tuti), Ryana Dea (Kokom), Guntara Hidayat (Koswara), Idrus Madani (Ustadz Kemed), Diaz Ardiawan (Sobri), Syahnaz Sadiqah (Dokter Clara), dan Faby Marcelia (Cucu).

\section{Problem Gender dalam Sinetron Dunia} Terbalik

Cerita yang diangkat dalam sinetron melukiskan kisah suami yang ditinggalkan istrinya karena harus bekerja di luar negeri.
Diceritakan bahwa Akum, Aceng, Idoy, dan Dadang, harus mendidik anak serta mengurus rumah tangga yang biasanya menjadi urusan para perempuan. Dadang merupakan suami paling beruntung karena istrinya mendapat penghasilan paling tinggi di antara yang lainnya. Hal ini lantas membuat dirinya sombong dan suka memamerkan kekayaannya. Aceng pun sering dibuat iri hati terhadapnya. Seringkali Aceng ingin membalasnya, namun Aceng terkadang malah kena getahnya. Akum dan Idoy lah yang kemudian menjadi penengah di antara keduanya.

Cerita ini mengambil latar belakang masyarakat Jonggol, Bogor, yang sebelumnya tinggal di Desa Cibarengkok. Karena terancam akan terkena longsor, mereka pindah ke Desa Ciraos. Desa Ciraos sendiri sebagai penyalur TKW terbanyak yang tidak terlepas dari peran Yoyoh sang calo TKW yang membujuk para calon TKW-nya. Dalam menyelesaikan masalah-masalah yang ada di Ciraos, warga desa biasanya akan meminta nasihat dari Ketua RW yang juga panutan bagi masyarakat, yakni Ustadz Kemed.

Berikut sebagian adegan (scene) yang menunjukkan pertukaran beban gender dalam sinetron Dunia Terbalik: 
a) Tokoh Aceng dan Akum sedang melakukan aktifitas mencuci pakaian di Sungai.

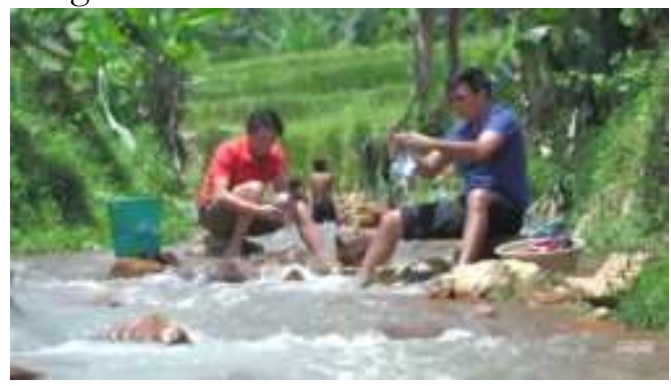

\section{Gambar 1}

Aceng dan Akum Mencuci Pakaian di Sungai

b) Saat Akum dan Aceng sedang mencuci, tiba-tiba datang Idoy membawa kabar tentang Dadang yang baru saja membeli HP baru.

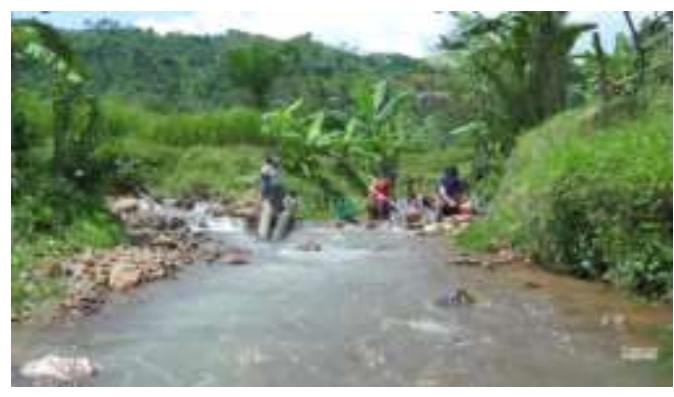

Gambar 2

Aceng, Akum, dan Idoy mencuci pakaian sambil bergosip di Sungai

c) Para tetangga menyambut kedatangan Ceu Esih yang baru pulang dari Arab

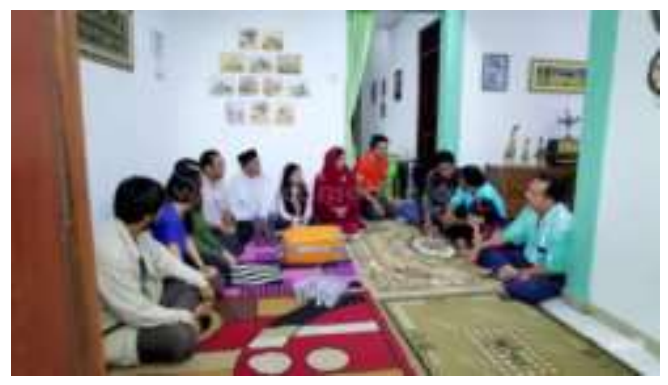

${ }^{20}$ Nasaruddin Umar, Argumen Kesetaraan Jender Perspektif Al-Qur'an (Jakarta: Dian Rakyat, 2010), 229
Gambar 3

Para tetangga menyambut kedatangan Ceu Esih dari Arab

d) Keberangkatan Ceu Esih menuju Bandara dengan tujuan untuk kembali mencari nafkah/bekerja sebagai TKW Arab.

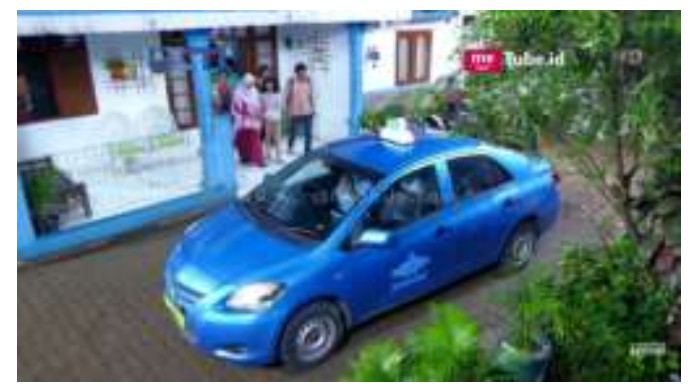

Gambar 4

Keberangkatan kembali Ceu Esih ke Arab

\section{Prinsip-Prinsip Kesetaraan Gender Menurut Nasaruddin Umar}

Nasaruddin Umar mengungkapkan beberapa variabel yang dapat digunakan sebagai ukuran dalam menganalisa prinsipprinsip kesetaraan gender dalam Alquran. ${ }^{20}$ Berikut adalah variabel-variabel yang dimaksud:

a. Laki-laki dan perempuan sama-sama sebagai hamba Allah

Di antara tujuan penciptaan manusia adalah untuk beribadah kepada Allah, sebagaimana disebutkan dalam surat AdhDhariyat ayat 56: 
An-Nisa' : Jurnal Kajian Perempuan \& Keislaman

Vol. 14, No. 1, April 2021

p-ISSN : $2086-0749$

e-ISSN : 2654-4784

\section{وَمَا خَلَقْتُ الْجِنَّ وَالإنْسَ إلا لِيَعْبُدُون}

"Dan Aku tidak menciptakan jin dan manusia melainkan supaya mereka menyembah-Ku."

Dalam kapasitasnya sebagai hamba, lakilaki tidak dibedakan dengan perempuan. Potensi dan peluang keduanya untuk menjadi hamba yang baik adalah sama. Baik laki-laki maupun perempuan, tidak dinilai berdasarkan perbedaan jenis kelaminnya tetapi pada tingkatan ketaqwaannya. Derajat ini dapat diraih oleh siapapun dan sama sekali tidak berkaitan dengan atribut kultural yang dibentuk manusia, termasuk atribut gender. Bahwa parameter manusia yang paling mulia adalah taqwa. Hal ini dinyatakan dalam Alquran surat Al-Hujurat ayat 13:

يَا أَيْهَها النَّاسُ إِنَّا خَلَقْنَاكُمْ مِنْ ذَكَرِ وَأُنْنَى وَجَعَلْنَاكُمْ

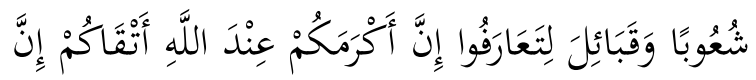<smiles>C[As](C)(C)N=[As]</smiles>

"Hai manusia, Sesunggubnya Kami menciptakan kamu dari seorang laki-laki dan seorang perempuan dan menjadikan kamu berbangsa - bangsa dan bersuku-suku supaya kamu saling kenal-mengenal. Sesunggubnya orang yang paling mulia diantara kamu disisi Allah ialah orang yang paling taqwa diantara kamu. Sesungguhnya Allab Maha mengetahui lagi Maha Mengenal."

Kekhususan-kekhususan yang diperuntukkan bagi laki-laki, seperti kedudukan suami lebih tinggi dari istri (Q.S. Al-Baqarah: 228), laki-laki merupakan pelindung perempuan (Q.S. An-Nisa: 34), memperoleh bagian warisan lebih banyak (Q.S. An-Nisa: 11), menjadi saksi yang efektif (Q.S. Al-Baqarah: 282), dan kebolehan berpoligami bagi yang memenuhi syarat (Q.S. An-Nisa: 3), semua itu tidak berimplikasi pada keutamaan laki-laki sebagai hamba. Kekhususan tersebut diberikan kepada lakilaki, yang jika dikaitkan dengan konteks sosial ketika ayat tersebut diturunkan, berkapasitas sebagai anggota masyarakat yang memiliki peran publik dan sosial yang dominan.

Sebagai hamba, laki-laki dan perempuan akan mendapatkan penghargaan sesuai dengan kadar pengabdiannya, sebagaimana disebutkan dalam surat An-Nahl ayat 97, yang artinya:

"Barangsiapa yang mengerjakan amal saleh, baik laki-laki maupun perempuan dalam keadaan beriman, maka sesunggubnya akan Kami berikan kepadanya kehidupan yang baik dan sesunggubnya akan Kami beri balasan kepada mereka dengan pabala yang lebih baik dari apa yang telah mereka kerjakan."

b. Laki-laki dan perempuan sebagai khalifah di bumi

Di samping untuk menjadi hamba yang tunduk, patuh, serta mengabdi kepada Allah, tujuan penciptaan manusia di muka bumi ini adalah untuk menjadi khalifah di bumi. Kapasitas kekhalifahan manusia 
dinyatakan dalam Alquran surat Al-An'am ayat 165 :

$$
\begin{aligned}
& \text { وَهُوَ الَّذِي جَعَلَكُمْ خَلَاَئِفَ الْأَرْضِ وَرَفَعَ بَضْضَكُمْ فَوْقَ }
\end{aligned}
$$

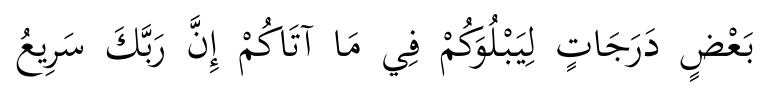

$$
\begin{aligned}
& \text { الْعِقَابِ وَإِنَّهُ لَغَفُورُ رَحِيمٌ }
\end{aligned}
$$

"Dan dialah yang menjadikan kamu penguasapenguasa di bumi dan Dia meninggikan sebahagian kamu atas sebabagian (yang lain) beberapa derajat, untuk mengujimu tentang apa yang diberikan-Nya kepadamu. Sesunggubnya Tuhanmu amat cepat sikesaan-Nya, dan sesunggubnya Dia Maha Pengampun lagi Maha Penyayang."

Dalam surat Al-Baqarah ayat 30, kapasitas tersebut kembali disebut:

وَإِذْ قَالَ رَبُكَكَ لِلْمَلائِكَة إنِّي جَاعِلْ فِي الأرْضِ خَلِيفَةً قَالُوا أَتَجْعَلُ فِيهَا مَنْ يُفْسِدُ فِيهَا وَيَسنفِكُ اللِِّمَاءَ وَنَخْنُ

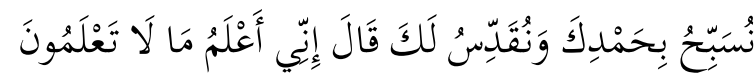
"Ingatlah ketika Tuhanmu berfirman kepada Para Malaikat, "Sesunggubnya Aku bendak menjadikan seorang khalifah di bumi." Mereka berkata, "Apakah Engkau hendak menjadikan orang yang merusak dan menumpabkan darab di sana, sedangkan kami bertasbih memuji-Mu dan menyucikan nama-Mu?" Dia berfirman, "Sesungguhnya aku mengetahui apa yang tidak kamu ketahui."

Kata khalifah dalam kedua ayat di atas tidak menunjuk kepada salah satu jenis kelamin tertentu. Dengan demikian, maknanya dapat menunjuk pada laki-laki dan perempuan. Artinya, laki-laki maupun perempuan mempunyai fungsi dan tanggung jawab kekhalifahan yang sama. Keduanya akan diminta untuk memerankan tugas-tugas kekhalifahannya di bumi.

c. Laki-laki dan perempuan menerima perjanjian primordial

Perjanjian primordial antara manusia dengan Tuhan bersifat universal, yaitu untuk semua manusia tanpa kecuali. Manusia di situ tentunya mencakup laki-laki dan perempuan. Keduanya terlibat dalam perjanjian tersebut. Menjelang kelahirannya, seorang anak manusia terlebih dahulu menerima perjanjian dengan Tuhannya, sebagaimana disebutkan dalam Alquran surat Al-A'raf ayat 172:

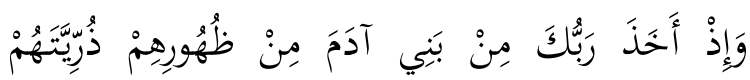

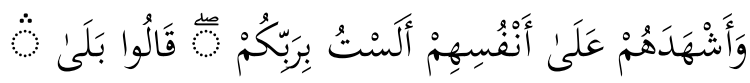

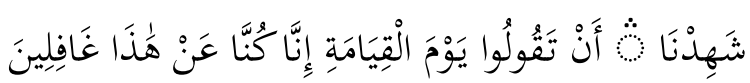
"Dan (ingatlab), ketika Tubanmu mengeluarkan keturunan anak-anak Adam dari sulbi mereka dan Allah mengambil kesaksian terhadap jiwa mereka (seraya berfirman): "Bukankah Aku ini Tuhanmu?" mereka menjawab: "Betul (Engkau Tuban kami), kami menjadi saksi". (kami lakukan yang demikian itu) agar di hari kiamat kamu tidak mengatakan: "sesunggubnya kami (Bani Adam) adalah orang orang yang lengah terhadap ini (keesaan Tuban)."

Menurut Fakhr al-Razi, seluruh anak manusia yang lahir di muka bumi ini telah berikrar akan keberadaan Tuhan. Ikrar tersebut disaksikan para malaikat. Semua manusia menyatakan kesaksiannya., tidak ada 
yang mengatakan "tidak". ${ }^{21}$ Dalam hal ini, Islam memandang bahwa tanggung jawab individual dan kemandirian berlangsung sejak dini, yaitu semenjak dalam kandungan. Tanggung jawab dan kemandirian ini berlaku untuk laki-laki dan perempuan. Tidak dikenal diskriminasi jenis kelamin dalam Islam. Lakilaki dan perempuan menyatakan ikrar ketuhanan yang sama.

Oleh karena itu, kepercayaan diri pada perempuan dalam Islam semestinya menjadi pengetahuan bawaan. Pengetahuan inilah yang menjadi dasar kesetaraan bagi laki-laki dan perempuan terbentuk sejak lahir, karena keduanya terlahir dengan membawa ikrar yang sama di hadapan Tuhan. Namun demikian, prinsip ini tidak dipandang signifikan, terutama ketika dikaitkan dengan drama kosmis yang menggambarkan Hawa menjadi penyebab dikeluarkannya Adam dari surga sehingga citra negatif dilabelkan begitu saja pada perempuan.

Dalam tradisi Islam, ayah dan suami memang memiliki otoritas khusus. Namun demikian, otoritas ini tidak menjadi alasan dibolehkannya mencampuri komitmen pribadi seorang perempuan dengan Tuhannya. Perempuan memperoleh hak sebagaimana halnya hak yang diberikan kepada laki-laki, termasuk untuk urusan yang bersifat keduniaan.

d. Adam dan Hawa terlibat secara aktif dalam drama kosmis

Apabila dianalisis secara objektif, tampak bahwa ayat-ayat yang menceritakan drama kosmis, yaitu cerita yang melukiskan pelanggaran terhadap perintah Tuhan yang dilakukan Adam dan Hawa kemudian menyebabkan keduanya terusir dari surga, menunjukkan peran aktif dari keduanya. Peran aktif ini ditekankan pada penggunaan kata ganti untuk dua orang (هم), yakni untuk Adam dan Hawa, seperti dapat dilihat dalam beberapa ayat berikut ini:

1) Dalam surat Al-Baqarah ayat 35 disebutkan bahwa Adam dan Hawa samasama diciptakan di surga dan memanfaatkan fasilitasnya:

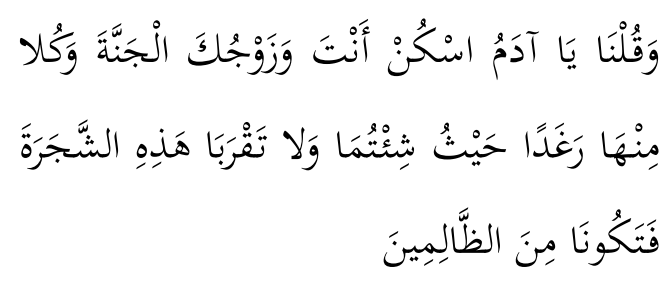

"Dan Kami berfirman, "Hai Adam, diamilah oleb kamu dan istrimu surga ini, dan makanlah makanan-makanannya yang banyak lagi baik di mana saja yang kalian sukai, tetapi janganlah kamu dekati pohon ini, yang menyebabkan kamu termasuk orangorang yang zalim."

21 Nasaruddin Umar, Argumen Kesetaraan Jender Perspektif Al-Qur'an, 235 
2) Dalam surat Al-A'raf ayat $20 \mathrm{~S}$ disebutkan bahwa syaitan menggoda keduanya dengan kualitas godaan yang sama:

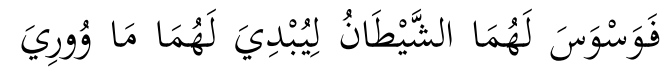
عَنْهُمَا مِنْ سَوْوَتِهِمَا وَقَالَ مَا نَهَاكُمَا رَبُكُكمَا عَنْ

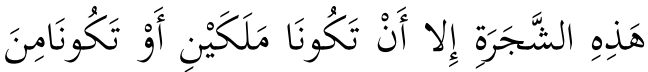
الْخَالِِِينَ

"Maka setan membisikean pikiran jahat kepada keduanya untuk menampakkan kepada keduanya apa yang tertutup dari mereka yaitu auratnya dan setan berkata: "Tuban kamu tidak melarangmu dari mendekati pohon ini, melainkan supaya kamu berdua tidak menjadi malaikat atau tidak menjadi orang yang kekeal (dalam surga)."

3) Adam dan Hawa sama-sama memakan buah khuldi dan kemudian menerima akibat jatuh ke bumi. Hal ini disebutkan dalam surat Al-A'raf ayat 22:

فَدَلالهُمَا بِغُرُورٍِ فَلَمَّا ذَاقًَا الشَّجَرَةَ بَدَتْ لَهُمَا

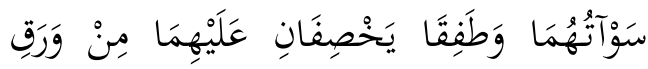

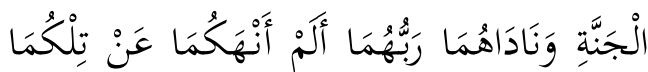

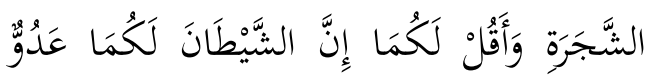
مُبِينْ

"Maka setan membujuk keduanya (untuk merasakan buah itu) dengan tipu daya. Tatkala keduanya telah merasai buah kayu itu, tampaklab bagi keduanya aurat-auratnya, dan mulailab keduanya menutupinya dengan daun-daun surga. Kemudian Tuban mereka menyeru mereka, "Bukankah Aku telah melarang kamu berdua dari pohon kayu itu dan Aku katakan kepadamu, 'Sesunggubnya setan itu adalah musuh yang nyata bagi kamu berdua'?."

4) Dalam surat Al-A'raf ayat 23 disebutkan bahwa Adam dan Hawa memohon ampun kepada Tuhan dan keduanya diampuni:

قَالا رَبَنَّا ظَلَمْنَا أَنْفُسَنَا وَإِنْ لَمْ تَغْفِرْ لَنَا وَتَرْحَمْنَا

$$
\text { لَنَكُونَنَّ مِنَ الْخَاسِرِينَ }
$$

"Keduanya berkata, "Ya Tuhan kami, kami telab menganiaya diri kami sendiri; dan jika Engkau tidak mengampuni kami dan memberi rahmat kepada kami, niscaya pastilah kami termasuk orang-orang yang merugi."

5) Dalam surat Al-Baqarah ayat 187 disebutkan bahwa Adam dan Hawa mengembangkan keturunan, saling melengkapi, dan saling membutuhkan setelah keduanya berada di bumi:

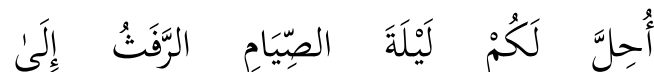

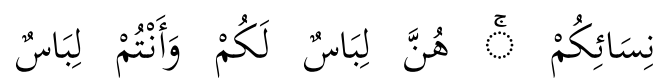

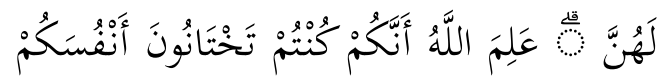
فَتَابَ عَعَيْكُمْ وَعَفَا عَنْكُمْ اِِ فَالْآنَ بَاشِرُوهُنَّ

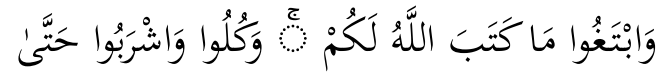
يَتَبَيَّنَ لَكُمُ الْخَيْطُ الْأَبْيَضُ ِِنَ الْخَيْطِط الْأَسْوَدِ

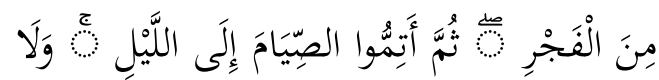

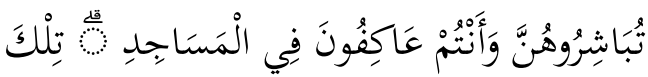




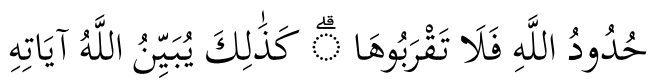

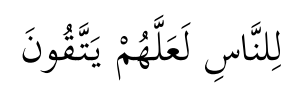

"Dibalalkan bagi kamu pada malam hari bulan puasa bercampur dengan isteri-isteri kamu; mereka adalab pakaian bagimu, dan kamupun adalab pakaian bagi mereka. Allah mengetabui bahwasanya kamu tidak dapat menahan nafsumu, karena itu Allah mengampuni kamu dan memberi maaf kepadamu. Maka sekarang campurilah mereka dan ikutilah apa yang telah ditetapkan Allab untukmu, dan makan minumlah bingga terang bagimu benang putih dari benang bitam, yaitu fajar. Kemudian sempurnakanlah puasa itu sampai (datang) malam, (tetapi) janganlah kamu campuri mereka itu, sedang kamu beri'tikeaf dalam mesjid. Itulah larangan Allah, maka janganlah kamu mendekatinya. Demikianlah Allah menerangkan ayat-ayat-Nya kepada manusia, supaya mereka bertaqwa."

e. Laki-laki dan perempuan berpotensi meraih prestasi

Peluang untuk meraih prestasi terbuka pada laki-laki dan perempuan. Hal ini ditegaskan Alquran pada ayat-ayat beriku:

1) Surat Ali Imran ayat 195:

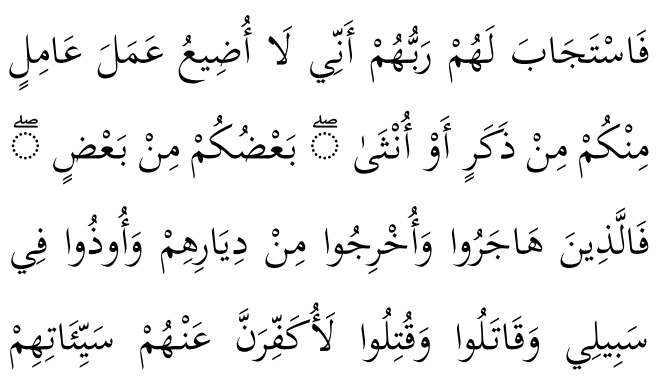

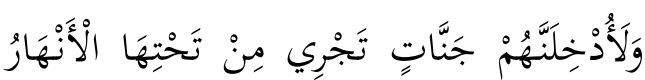

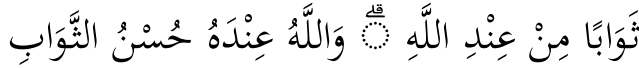
"Maka Tuban mereka memperkenankan permobonannya (dengan berfirman): "Sesungguhnya Aku tidak menyia-nyiakan amal orang-orang yang beramal di antara kamu, baik laki-laki atau perempuan, (karena) sebagian kamu adalab turunan dari sebagian yang lain. Maka orang-orang yang berbijrah, yang diusir dari kampung halamannya, yang disakiti pada jalan-Ku, yang berperang dan yang dibunub, pastilab akan Ku-hapuskan kesalahan-kesalahan mereka dan pastilah Aku masukean mereka ke dalam surga yang mengalir sungai-sungai di bawahnya, sebagai pabala di sisi Allah. Dan Allah pada sisi-Nya pabala yang baik."

2) Surat An-Nisa ayat 124:

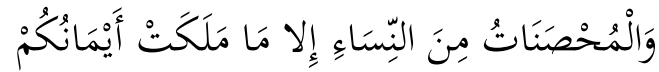

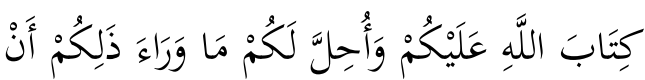

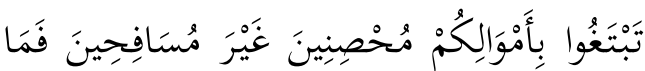

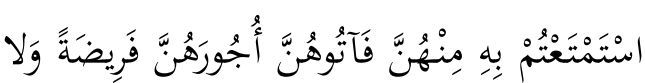

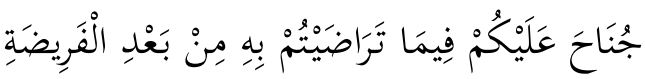
إِنَّ اللَّة كَانَ عَلِيلمًا حَكِيمًا

"Dan (diharamkan juga kamu menikabi) perempuan yang bersuami, kecuali budakbudak perempuan (tawanan perang) yang kamu miliki sebagai ketetapan Allah atas kamu. Dan dibalalkan bagimu selain (perempuan-perempuan) yang demikian itu jika kamu berusaha dengan hartamu untuk menikabinya bukan untuk berzina. Maka karena kenikmatan yang telab kamu 


\section{Nani Widiawati, Nurkhopipah}

dapatkan dari mereka, berikanlah maskawinnya kepada mereka, sebagai suatu kewajiban. Tetapi tidak mengapa jika termyata di antara kamu telab saling merelakannya, setelah ditetapkan. Sesunggubnya Allab Maba Mengetabui lagi Maha Bijaksana."

3) Surat An-Nahl ayat 97:

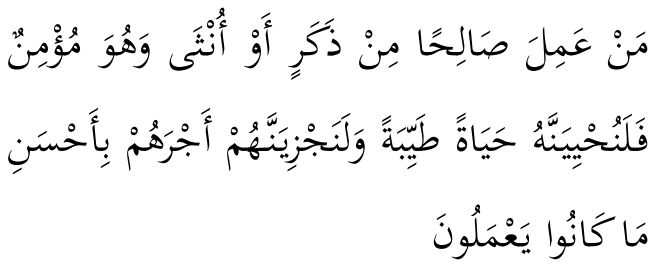

"Barang siapa mengerjakan amal saleh, baik laki-laki maupun perempuan dalam keadaan beriman, maka pasti akan Kami berikan kepadanya kebidupan yang baik dan akan Kami beri balasan dengan pabala yang lebih baik dari apa yang telab mereka kerjakan."

4) Surat Al-Mu'minun ayat 40:

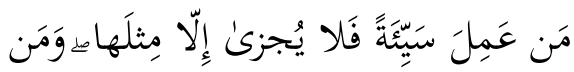

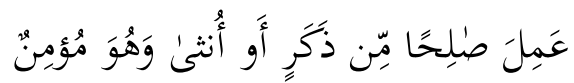

$$
\begin{aligned}
& \text { فَأُولِيُكَكَ يَدخُلونَ الجَنَّةَ يُرَزقونَ فيها بِغَيَرِ } \\
& \text { حسابٍ }
\end{aligned}
$$

"Barang siapa mengerjakan perbuatan jahat, maka dia akan dibalas sebanding dengan kejahatan itu. Dan barang siapa mengerjakan kebajikan, baik. laki-laki maupun perempuan sedangkan dia dalam keadaan beriman, maka mereka akan masuk surga, mereka diberi rezekei di dalamnya tidak terbingga."

Ayat-ayat di atas mengisyaratkan konsep kesetaraan gender yang ideal. Terdapat ketegasan bahwa prestasi individual, baik secara spiritual maupun profesional, tidak mesti dimonopoli oleh salah satu jenis kelamin. Laki-laki dan perempuan memperoleh kesempatan yang sama dalam meraih kesuksesan. Namun praktiknya dalam kehiduoan masyarakat, konsep ini membutuhkan tahapan sosialisasi yang kontinyu, karena masih terdapat sejumlah kendala kultural yang sulit diselesaikan.

Dalam konteks ini, salah satu misi Alquran ialah terwujudnya keadilan yang mencakup segala segi kehidupan umat manusia, baik laki-laki maupun perempuan, baik dalam kapasistas sebagai individu maupun sebagai anggota masyarakat. Alquran tidak mentolelir segala bentuk diskriminasi, antara lain diskriminasi yang berakar dari pembedaan jenis kelamin. Jika terdapat suatu interpretasi atau tafsir yang mengindikasikan adanya bias diskriminatif yang bertentangan dengan nilai kemanusiaan, maka interpretasi atau tafsir tersebut terbuka untuk dinterpretasi kembali.

\section{Interpretasi Gender Sinetron Dunia}

\section{Terbalik Berdasarkan Pemikiran}

\section{Nasaruddin Umar}

Berdasarkan hasil interpretasi penulis, terdapat beberapa prinsip pemikiran Nasaruddin Umar yang dapat digunakan untuk menerjemahkan isi sinetron Dunia Terbalik terkait argumen kesetaraan gender Nasaruddin Umar. Prinsip-prinsip tersebut adalah sebagai berikut: 
a. Laki-laki dan perempuan sederajat

Menjadi manusia laki-laki atau perempuan adalah kehendak Tuhan, dan Tuhan tidak pernah menganggap yang satu lebih mulia dari yang lain. Jadi, pada hakikatnya laki-laki dan perempuan itu sama dan sederajat dalam kapasitasnya sebagai seorang hamba Tuhan. Adapun pembedaan tentang status sosial laki-laki lebih tinggi daripada perempuan, itu merupakan bagian dari pengaruh budaya.

Islam menempatkan perempuan pada posisi yang setara dengan laki-laki. Keduanya dapat hidup dengan saling membantu dan mengisi. Masing-masing memiliki karakteristik berbeda, sama-sama memiliki kekurangan dan kelebihan, yang bisa menjadi potensi untuk saling menguatkan dan mendukung satu sama lain. $^{22}$

Alquran surat At-Taubah ayat 71 mengukuhkan pandangan Islam terhadap kesetaraan perempuan dan laki-laki. Dalam penerimaan hak serta menunaikan kewajiban, Islam tidak membedakan keduanya. Perempuan dapat dijadikan partner laki-laki dalam ber-amar ma'ruf naby munkar, demikian

22 Muhammad Taufiq Taufiq, 'Kesetaraan Gender Perspektif Kosmologi Islam', Tasfiyah, 2.2 (2018)

<https://doi.org/10.21111/tasfiyah.v2i2.2578>.

23 MUHAMMAD ROIHAN DAULAY, 'Pandangan Islam Tentang Gender', Jurnal Kajian Gender Dan Anak, 2020 <https://doi.org/10.24952/gender.v2i1.2168>. sebaliknya. Islam tidak membedakan ketaatan perempuan dan laki-laki sebab keduanya memiliki posisi yang sama. ${ }^{23}$ Menurut Lisnawati Shaleh, keduanya memiliki peluang yang sama untuk menjadi hamba yang sempurna. Keduanya mempunyai fungsi dan peran yang sama, yaitu sebagai khalifah, dan dituntut untuk sama-sama mempertanggungjawabkan tugas-tugas kekhalifahannya di bumi dalam posisi yang sama di hadapan Allah. ${ }^{24}$

Dengan argumen kesetaraan ini, maka bias gender sesungguhnya tampak mulai dari judul sinetron itu sendiri, yaitu "dunia terbalik". Dengan judul tersebut, seolah-olah jika perempuan bekerja sementara suami berada di rumah adalah hal yang kontradiktif. Padahal, bekerja adalah bentuk amal shalih. Bekerja di sini diinterpretasi secara universal, baik bekerja di rumah maupun bekerja di luar rumah. Islam sendiri melihat perempuan dengan penuh kemandirian. ${ }^{25}$

b. Kodrat perempuan adalah melahirkan dan menyusui, sedangkan mengurus rumah dan anak adalah tanggung jawab bersama suami istri.

\footnotetext{
${ }^{24}$ Lisnawati Shaleh, 'PEREMPUAN DALAM LINTASAN SEJARAH: MENEPIS ISU KETIDAKSETARAAN GENDER DALAM ISLAM', El-Mashlahah, 2019 <https://doi.org/10.23971/el-mas.v9i1.1314>. $25 \mathrm{~J}$ Amin, 'Permasalahan Gender Dalam Perspektif Islam', BUANA GENDER: Jurnal Studi Gender Dan ..., 2019.
} 
Urusan ranah domestik dan mengurus anak adalah tanggung jawab bersama, dalam peran laki-laki sebagai suami dan perempuan sebagai istri. Karena hak-hak seperti memeroleh pengetahuan, keterampilan, pendidikan tinggi, dan sebagainya, tidak hanya diperuntukkan bagi kaum laki-laki, melainkan bagi kaum perempuan juga. Laki-laki dan perempuan, sama-sama berpotensi meraih prestasi.

Prestasi sendiri berkaitan dengan potensi individual yang terlepas dari kategorisasi laki-laki atau perempuan. Dalam hal tertentu, laki-laki memiliki kelebihan daripada perempuan, demikian sebaliknya. Ada kalanya laki-laki bisa melakukan lebih baik daripada perempuan dan adakalanya sebaliknya. ${ }^{26}$ Dengan demikian, jenis kelamin bukan sebuah kategori biner untuk mempertimbangan sebuah keragaman sebab ada hal yang dapat dijadikan prediktor yang lebih baik. $^{27}$

Pembidangan ruang domestik dan publik dengan konotasi gender yang kuat, bahwa berprestasi di ruang publik lebih berkelas daripada di ruang domestik sesungguhnya sudah harus direkonstruksi. Substansinya adalah menempuh hidup secara

26 Kimmo Eriksson, Marie Björnstjerna, and Irina Vartanova, 'The Relation Between Gender Egalitarian Values and Gender Differences in Academic Achievement', Frontiers in Psychology, 2020 <https://doi.org/10.3389/fpsyg.2020.00236>.

27 Anna Lindqvist, Marie Gustafsson Sendén, and Emma A. Renström, 'What Is Gender, Anyway: A berkualitas atau berprestasi, baik di rumah maupun di luar rumah, baik laki-laki-laki maupun perempuan. Dengan begitu, maka yang menjadi persoalan adalah kesempatan serta relevansi keahlian, dan persoalan kesempatan serta keahlian bukan persoalan yang kebalik-balik sebagaimana yang dimunculkan dalam judul sinetron tersebut. Pertukaran peran antara laki-laki dan perempuan bukan merupakan masalah jika diterapkan secara adil bagi kedua belah pihak.

Hal ini senada dengan pernyataan Suhada bahwa Islam menjunjung tinggi konsep keadilan bagi siapapun, baik laki-laki maupun perempuan. Islam merupakan agama yang terdepan dalam mengusung prinsip keadilan dengan tidak memberikan prestise hanya pada satu jenis kelamin. ${ }^{28}$

c. Laki-laki dan perempuan harus memiliki kesamaan peran dan tanggung jawab dalam ranah publik dan domestik.

Dalam realitas kehidupan manusia, sifat kuat diidentifikasi pada kaum laki-laki sementara sifat lemah diberikan kepada perempuan. Dengan asumsi tersebut, maka tempat perempuan adalah di rumah. Sementara laki-laki, dengan maskulinitas yang dimilikinya, lebih pantas untuk berhadapan

Review of the Options for Operationalising Gender', Psychology and Sexuality, 2020 <https://doi.org/10.1080/19419899.2020.1729844>.

${ }^{28}$ Suhada Suhada, 'Kesetaraan Gender: Posisi Kepemimpinan Perempuan Dalam Islam', Mumta‡: Jurnal Studi Al-Qur'an Dan Keislaman, 2019 <https://doi.org/10.36671/mumtaz.v3i2.39>. 
dengan problem di ruang publik yang dinilai lebih berat.

Pekerjaan mengurus rumah, mencuci pakaian, mengurus anak dan segala hal yang berkaitan dengan ranah domestik, sama-sama harus dimiliki dan dijalankan oleh laki-laki dan perempuan, termasuk urusan mencari nafkah. Dengan demikian, bukan hal yang luar biasa jika dalam kehidupan berrumah tangga seorang suami memasak, mencuci, mengasuh anak, atau pekerjaan-pekerjaan domestik lainnya.

\section{Simpulan}

Analisis sinetron Dunia Terbalik yang diberlakukan mulai episode 1 sampai 150, menunjukkan bahwa problem gender dalam sinetron Dunia Terbalik adalah mengungkap pertukaran peran gender antara laki-laki dengan perempuan.

Prinsip-prinsip kesetaraan gender menurut Nasaruddin Umar, bahwa laki-laki dan perempuan adalah sebagai hamba, sebagai khalifah di bumi, keduanya menerima perjanjian primordial, dan sama-sama terlibat secara aktif dalam drama kosmis, sehingga dengan kesamaan yang dimilikinya, keduanya berpotensi meraih prestasi.

Interpretasi gender dalam sinetron Dunia Terbalik berdasarkan pemikiran Nasaruddin Umar menunjukkan bahwa, berdasarkan prinsip-prinsip kesetaraan gender dalam Islam, pertukaran peran laki-laki dengan perempuan dalam ruang domestik dan ruang publik bukan merupakan persoalan.

Sebagai diskusi, perlu disampaikan bahwa dalam memandang peran gender yang ideal, sinetron Dunia Terbalik dimulai dari anggapan bahwa kodrat laki-laki adalah mencari nafkah, sedangkan perempuan memiliki kodrat mengurus anak dan rumah tangga. Idealitas peran gender dalam sinetron ini menunjukkan bahwa sinetron Dunia Terbalik hadir dari latar belakang pemikiran kultural, yakni anggapan bahwa derajat lakilaki lebih tinggi daripada perempuan.

Atas dasar itu, sebagai evaluasi, perlu kiranya setiap segmen acara televisi tetap dapat mempertahankan misi idealnya sebagai media untuk mencerdaskan bangsa, media informasi yang dapat menyampaikan pesan-pesannya dengan benar, sekalipun dalam segmen komedi. Dengan demikian, produksi sinetron tetap dapat membuka wawasan dalam memahami persoalan gender, memberikan gambaran objektif baik secara konseptual maupun normatif sehingga dapat dipahami semua pihak, serta dapat menemukan akar persoalan yang melatarbelakangi suatu persoalan gender.

\section{Daftar Pustaka}

Amanda, Anisa Tri, 'Desakralisasi Figur Ustadz Dalam Sinetron (Analisis Isi 
Terhadap Figur Ustadz Kemed Dalam Sinetron Dunia Terbalik Di RCTI)', KOMUNIKA, 2020

<https://doi.org/10.22236/komunika.v $7 \mathrm{i} 1.5566>$

Amin, J, 'Permasalahan Gender Dalam Perspektif Islam', BUANA GENDER: Jurnal Studi Gender Dan ..., 2019

AR, Muhammad Yusuf, and Atia Vitalia Aswadany, 'PERSEPSI IBU RUMAH TANGGA TERHADAP PERAN GENDER PADA TAYANGAN SINETRON "DUNIA TERBALIK" RCTI', Jurnal Jurnalisa, 2019 $<$ https://doi.org/10.24252/jurnalisa.v5i $1.10172>$

Ariya, Tri Yuni, 'Resepsi Pasangan Suami Istri Terhadap Pergeseran Peran Gender Dalam Sinetron Dunia Terbalik Rcti (Analisis Resepsi Model Stuart Hall)', Journal of Chemical Information and Modeling, 2018

Astagini, Nuria, and Fitriyah Nurhidayah, 'Hiperrealitas Sosok Suami Tenaga Kerja Wanita (TKW) Dalam Sinetron Dunia Terbalik Di RCTI', WIDYAKALA JOURNAL， 2017 $<$ https://doi.org/10.36262/widyakala.v $4 \mathrm{i} 2.58>$

Bohls, Elizabeth A., 'Gender', in Handbook of British Travel Writing, 2020 <https://doi.org/10.1515/9783110498 974-004>

Breda, Thomas, Elyès Jouini, Clotilde Napp, and Georgia Thebault, 'Gender Stereotypes Can Explain the GenderEquality Paradox', Proceedings of the National Academy of Sciences of the United States of America, 2020 $<$ https://doi.org/10.1073/pnas.200870 4117>

DAULAY, MUHAMMAD ROIHAN, 'Pandangan Islam Tentang Gender', Jurnal Kajian Gender Dan Anak, 2020 <https://doi.org/10.24952/gender.v2i1 $.2168>$
Dewi, R, 'KEDUDUKAN PEREMPUAN DALAM ISLAM DAN PROBLEM KETIDAKADILAN GENDER', NOURA: JURNAL KAJLAN GENDER D AN ANAK, 2020

Eriksson, Kimmo, Marie Björnstjerna, and Irina Vartanova, 'The Relation Between Gender Egalitarian Values and Gender Differences in Academic Achievement', Frontiers in Psychology, 2020 <https://doi.org/10.3389/fpsyg.2020.0 0236>

Gani, Rusna, 'ISLAM DAN KESETARAAN GENDER', AL-WARDAH, 12.2 (2019) <https://doi.org/10.46339/alwardah.v12i2.139>

Hariatiningsih, Laurensia Retno, 'Persepsi Mahasiswa BSI Kaliabang Pada Tayangan Drama Komedi Dunia Terbalik Episode 151 Di RCTI ( Studi Tentang Persepsi Mahasiswa BSI Kaliabang )', Cakrawala, 2018

Izharuddin, Alicia, Gender and Islam in Indonesian Cinema, Gender and Islam in Indonesian Cinema, 2017 <https://doi.org/10.1007/978-981-102173-2>

Lindqvist, Anna, Marie Gustafsson Sendén, and Emma A. Renström, 'What Is Gender, Anyway: A Review of the Options for Operationalising Gender', Psychology and Sexuality, 2020 <https://doi.org/10.1080/19419899.20 20.1729844>

Murfi, Ali, 'Bias Gender Dalam Buku Teks Pendidikan Agama Islam Dan Kristen', Jurnal Pendidikan Islam, 3.2 (2014) $<$ https://doi.org/10.14421/jpi.2014.32. 267-288>

Ratnasari, Hesti, and Departemen Ilmu Komunikasi, 'Penerimaan Khalayak Terhadap Pertukaran Peran Gender Antara Laki-Laki Dan Perempuan Dalam Sinetron Dunia Terbalik Di RCTI', Interaksi Online, 2018

Rizki, Filantropi Nola, and Lulus Irawati, 
An-Nisa' : Jurnal Kajian Perempuan \& Keislaman

Vol. 14, No. 1, April 2021

p-ISSN : $2086-0749$

e-ISSN : 2654-4784

'Aspek Pendidikan Karakter Dalam Sinetron "Dunia Terbalik" Dan Sumbangannya Sebagai Materi Pembelajaran Sastra Indonesia Di Sekolah', Linguista: Jurnal Ilmiah Bahasa, Sastra, Dan Pembelajarannya, 2018 $<$ https://doi.org/10.25273/linguista.v2i $1.2687>$

Shaleh, Lisnawati, 'PEREMPUAN DALAM LINTASAN SEJARAH: MENEPIS ISU KETIDAKSETARAAN GENDER DALAM ISLAM', ElMashlabah, 2019

<https://doi.org/10.23971/elmas.v9i1.1314>

Solong, Najamuddin Petta, and Rullyjanto Podungge, 'BIAS GENDER DALAM PENDIDIKAN ISLAM', Irfani, 2019 $<$ https://doi.org/10.30603/ir.v15i1.105 $3>$

Suhada, Suhada, 'KESETARAAN GENDER: POSISI KEPEMIMPINAN PEREMPUAN DALAM ISLAM', Mumtaæ: Jurnal Studi Al-Qur'an Dan Keislaman, 2019 $<$ https://doi.org/10.36671/mumtaz.v3i $2.39>$

Taufiq, Muhammad Taufiq, 'Kesetaraan Gender Perspektif Kosmologi Islam', Tasfiyah, $\quad 2.2$ <https://doi.org/10.21111/tasfiyah.v2i $2.2578>$

Tissier-Desbordes, Elisabeth, and Luca M. Visconti, 'Gender after Gender: Fragmentation, Intersectionality, and Stereotyping', Consumption Markets and Culture, 2019 <https://doi.org/10.1080/10253866.20 18.1512238>

Umar, Nasaruddin, Argumen Kesetaraan Jender Perspektif Al-Qur'an (Jakarta: Dian Rakyat, 2010)

Wahid, Umaimah, and Ferrari Lancia, 'Exchange of Public and Domestic
Roles of Men and Women in Indonesian Television Soap Opera "Dunia Terbalik" (Analysis of Social Discourse M. K. Halliday)', Advanced Science Letters, 2018 <https://doi.org/10.1166/asl.2018.1 2427> 